\title{
The Brazilian iNDC under the scope of the "Consulta Clima": an investigation into the preparation process of the Brazilian targets presented at COP 21
}

\author{
IDébora Naidhig*, Maria Cristina Oliveira Souza, Rosana Icassatti Corazza
}

\begin{abstract}
IIn 2013, in Warsaw, COP-19 started the discussion for the elaboration of a new global climate agreement. It was agreed that each country would submit its "intended Nationally Determined Contribution" (iNDC) over the course of 2015, presenting its expected contributions to the global effort to mitigate and adapt to climate change. In the case of Brazil, the process of elaborating its iNDC included a consultation stage with civil society and non-governamental actors (NGA), the "Climate Consultation". This project presents results of a PIBIC sponsored research on the theme, with the presentation of actors and segments that were present at the eight sessions of the "Climate Consultation" Process, for the elaboration of the country's iNDCs according to themes and sectors: public health; energy, industry, transport and cities; agriculture, forestry and land use; Public sector; private and business sectors; third sector and academia.
\end{abstract}

\section{Key words: \\ "Consulta Clima"; intended Nationally Determied Contribution, Paris Agreement.}

\section{Introduction}

The Paris Agreement, the official document that sealed the 21st Conference of the Parties in 2015 in Paris, set objectives, measures and deadlines for mitigation and adaptation to the impacts of climate change. (BRAZIL, 2015). At the preparatory stage, countries presented their "Intended Nationally Determined Contributions". In this paper one presents the public consultation process organized by the Ministry of Foreign Affairs to formulate the Nationally Determined Contributions (iNDCs) of the country, with emphasis on the Consultation Climate Process.

\section{Results and Discussion}

In Brazil, the process of preparation and submission of the iNDC began in 2013, when the country suggested at COP 19 that the iNDC be opened for public consultation. The Consultation Climate was the process conducted by the Ministry of Foreign Affairs in consultation with civil society in order to support the process of elaboration of the country's iNDC. The consultations were carried out in two phases. The first took place between May 26 and July 22, 2014, based on an online questionnaire, available on the Public Diplomacy blog until mid-2015. In the second phase, from August 25 to November 23, 2014, a preliminary report, available on the same blog, was submitted to a new round of consultations, by electronic means and at thematic meetings with interested sectors, with a live webcast, from September 8 to 12,2014 , at the Itamaraty Palace in Brasilia.

The methodology included, among other strategies: a) official documents analysis; b) hearing and analysis of the videos of the consultations of the Climate Consultation; and c) identification of main actors involved and their positions. It was possible to identify actors and segments present at the eight sessions of the "Climate Consultation" Process, for the elaboration of the country's iNDCs according to themes and sectors: public health; energy, industry, transport and cities; agriculture, forestry and land use; Public sector; private and business sectors; third sector (NGOs) and academia. The eight face-to-face sessions that were part of the Climate Consultation Process brought to the fore the litigation of various actors, representatives of NGA's, public authorities, and organized civil society, who were present. Many of the actors who participated in the sessions pointed to the need for greater transparency and communication with civil society and questioned the participatory nature of the process, which should include representatives of a broader public.

\section{Conclusions}

Positions of the representatives of different sectors and segments showed some agreements, but also conflicts, as well as problems of mutual understanding or clarification on issues put on the agenda. The case of AFOLU (Agriculture, Forests and Land Use) calls attention. AFOLU corresponds to the sectors with the highest emissions in the country and in which business expansion has the greatest impact in the near future, in terms of increasing emissions. During this session, one can identify disagreements over: needs for mitigation measures; on the measures themselves, for example the use of market mechanisms to encourage and make more flexible the achievement of targets to be agreed Paris Agreement; and on issues such as zero illegal deforestation, especially regarding the extent of other biomes, especially the cerrado. The lack of availability of the full documents for Internet access made it difficult to assess the participatory nature of the process. Even so, the present work reached the main results expected by the analysis of the audiovisual documents and media available for the consultation process for the elaboration of the Brazilian contributions. In a possible continuation of this work, the Access Law will be used for more detail on the profiles of the participants, the nature of the process and deepening of the analysis.

\section{Acknowledgement}

We acknowledge CNPq and PRP/UNICAMP for institutional support in form of a PIBIC grant to Débora Naidhig (118141/2018-0). We are indebted also to researchers from LABTTS, for first reading of the manuscript and discussion of first results.

${ }^{1}$ MINISTÉRIO DAS RELAÇÕES EXTERIORES - BRASIL. Pretendida Contribuição Nacionalmente Determinada para consecução do Ministério Do Meio Ambiente - Brasil (UNFCCC). Disponível em: <http://www.mma.gov.br/clima/convencao-das-nacoes-unidas >. 